\title{
Polymorphism of the 5-HT1B Receptor Gene (HTR1B): Strong Within-Locus Linkage Disequilibrium without Association to Antisocial Substance Dependence
}

Henry R. Kranzler, M.D., Carlos A. Hernandez-Avila, M.D., and Joel Gelernter, M.D.

Serotonergic abnormalities may be present in individuals with either substance dependence (SD) or antisocial personality disorder (ASPD), disorders that occur together commonly. Consequently, genes encoding serotonin (5-HT) receptors are candidates for genetic studies of both disorders. Lappalainen et al. (1998) found evidence for linkage of antisocial alcoholism to HTR1B (the locus encoding the 5-HT1B receptor) in both Finns and Southwestern American Indians, and of allelic association of a G861C polymorphism at that locus with antisocial alcoholism in Finns. Unless the G861C polymorphism is found to be functional, it must be in linkage disequilibrium (LD) with a functional variant for it to be of physiological significance. Methods: The present study evaluated LD across three polymorphic systems at HTR1B and haplotype frequencies and allelic association of these systems with both $S D$ generally and alcohol dependence $(A D)$ specifically, with or without a comorbid antisocial diagnosis. Subjects were 370 European Americans (EAs) and 123 African Americans (AAs). Results: Although there was strong evidence for $L D$ across polymorphic systems in both populations, there was no evidence for association to SD or $A D$, either alone or with a comorbid antisocial diagnosis. Conclusion: Despite no evidence in this study for allelic association of HTR1B to antisocial substance dependence, further evaluation of the hypothesized association is warranted in other population groups.

[Neuropsychopharmacology 26:115-122, 2002] (C) 2001 American College of Neuropsychopharmacology. Published by Elsevier Science Inc.
KEY WORDS: Population genetics; Alcohol dependence; Drug dependence; Serotonin receptor; Polymorphism; Allelic association; 5-HT1B; HTR1B

From the Alcohol Research Center, Department of Psychiatry, University of Connecticut School of Medicine (HRK, CAH-A) Farmington, CT, Department of Psychiatry, VA Connecticut Healthcare System, West Haven Campus (JG) West Haven, CT, and Department of Psychiatry, Yale University School of Medicine (JG) New Haven, CT.

Address correspondence to: Joel Gelernter, M.D., VA CT Healthcare Center, Psychiatry 116A2, West Haven, CT 06516; Phone: 203932-5711 x3599; Fax: 203-937-3897; E-mail: joel.gelernter@yale.edu

Received February 2, 2001; revised February 5, 2001; accepted April 9, 2001.

Online publication: 5/14/01 at www.acnp.org/citations/ Npp050401116.
Antisocial personality disorder (ASPD) is highly prevalent among individuals with substance dependence (SD), both in clinical samples and in the general population. The National Comorbidity Survey (Kessler et al. 1994, 1996) and the Epidemiological Catchment Area Study (Regier et al. 1990) showed that, although the lifetime prevalence of ASPD ranges from 2.6-3.5\%, its prevalence is $9.8-14.3 \%$ among those with a lifetime SD diagnosis. In clinical samples, the median prevalence of ASPD is $18 \%$ among individuals with alcohol dependence (AD) and 24\% among those with cocaine or opioid dependence (Verheul et al. 1998).

Studies of the genetic basis of SD and ASPD have provided evidence both for overlapping vulnerability and 
for unique genetic factors. Cadoret et al. (1986, 1995), using an adoption study design, found evidence of two genetic pathways to drug abuse/dependence. The first pathway involved a direct contribution from alcoholic biological parents. The second pathway involved the presence in biological parents of ASPD, with the manifestation in the adopted offspring of aggressiveness, conduct disorder, ASPD, and, ultimately, drug abuse/dependence. These two pathways are consistent with recent research that has identified two subtypes of alcoholism (Bohman et al. 1987; Babor et al. 1992) and drug dependence (Ball et al. 1995, 1998; Feingold et al. 1996).

Serotonergic neurotransmission appears to play an important role in mediating impulsive behaviors (Soubrie 1986). Acute administration of ethanol increases the concentration of 5-HT in the brain, whereas chronic administration decreases 5-HT levels. Decreased serotonergic activity following chronic ethanol administration can lead to behavioral disinhibition, including impulsive aggression (Higley et al. 1992, 1996). The serotonergic system also plays a role in the response to a variety of drugs that are self-administered by animals and abused by humans, including cocaine (Parsons et al 1998; Rocha et al 1998a). These drugs have been shown to release dopamine in the nucleus accumbens and ventral tegmental area (VTA), areas that are thought to provide a common pathway for reinforcement (Di Chiara and Imperato 1988). In turn, 5-HT receptors, including 5-HT1B receptors, are involved in the modulation of dopaminergic activity. For example, activation of the 5HT1B receptor increases striatal dopamine release, which correlates with enhanced locomotor and motor activity, an effect that is blocked by a 5-HT1B antagonist (Kriem et al. 1996). Furthermore, the central infusion of 5-HT potentiates the inhibitory effect of dopamine on neurons of the VTA (Brodie and Bunney 1996).

Data from humans also show inter-individual variation in central serotonergic functioning among patients diagnosed with ASPD, AD, or drug dependence. For example, antisocial alcoholics have lower basal cerebrospinal fluid levels of 5-HIAA than do controls (Limson et al. 1991; Virkkunen et al. 1994). Substance-dependent patients and antisocial men also show blunted cortisol and prolactin responses to a challenge with the 5-HT agonists fenfluramine and $d$-fenfluramine ( $\mathrm{O}^{\prime}$ Keane et al. 1992; Moss et al. 1990).

Studies looking at the effects of tryptophan depletion also support the notion that low 5-HT tone in the CNS facilitates aggressive behaviors. For example, men with high basal levels of hostility or antisocial traits experienced increased hostility following tryptophan depletion (Cleare and Bond 1995). Furthermore, low central serotonergic tone in combination with alcohol administration has been reported to produce independent, but additive, effects on aggressiveness in men (Pihl et al. 1995).
Based on this literature, the genes encoding 5-HT receptors (HTR1B in particular) are likely candidates for studies of both SD and ASPD. Interestingly, a cluster of four high preference sites for alcohol, morphine and cocaine was mapped by QTL analysis to chromosome 9 $(42-48 \mathrm{cM})$ in mice, a region in close proximity to the site for the 5-HT1B receptor gene (Crabbe et al. 1994). Furthermore, transgenic mice lacking 5-HT1B receptors showed increased aggressive behavior (Saudou et al. 1994) and increased spontaneous alcohol drinking (Crabbe et al. 1996). Additionally, this rodent model showed a 3-fold increase in the rate of cocaine self-administration compared with wild-type animals (Rocha et al. 1998b).

5-HT1B receptors are located both postsynaptically and presynaptically and include autoreceptors that regulate the release of 5-HT (Zifa and Fillion 1992). These receptors have a putative secondary structure of seven transmembrane domains common to $G$ protein-coupled receptors (Julius 1991). 5-HT1B receptors are negatively coupled to adenylate cyclase (Zifa and Fillion 1992). The gene encoding the 5-HT1B receptor was initially cloned in rat (Adham et al. 1992; Voigt et al. 1991) and mouse (Maroteaux et al. 1992), and subsequently mapped to chromosome 6 in humans (locus HTR1B; Lappalainen et al. 1995). Direct analysis of its sequence variation has also been conducted (Sidenberg et al. 1993; Lappalainen et al. 1995; Nöthen et al. 1994; Cargill et al. 1999). A common polymorphism was identified in the gene by Sidenberg et al. (1993) using HincII restriction enzyme digestion; quite possibly this is the same polymorphism later identified and characterized by Lappalainen et al. (1995) using a PCR-RFLP method (G861C). Nöthen et al. (1994) identified four polymorphisms in the gene, including one that results in an amino acid exchange and three located in the $5^{\prime}$ untranslated region. Of these polymorphisms, only the $\mathrm{T}$ to $G$ transversion at nt -261 (T-261G) was found in more than one of the 46 individuals screened. Cargill et al. (1999) identified single nucleotide polymorphisms (SNPs) in a range of genes of neuropsychiatric interest, including HTR1B. One of the polymorphisms they identified was C129T, a common, though silent, polymorphism in the coding sequence. Huang et al. (1999) also identified C129T, which they genotyped by SSCP, and found to be in complete linkage disequilibrium (LD) with G861C.

Lappalainen et al. (1998) tested for linkage with HTR1B in two groups: 640 Finnish subjects with a high prevalence of alcoholism and ASPD, and a large multigenerational Southwestern American Indian family with a high rate of alcoholism $(n=416)$. Among the Finns, sib pair analysis showed significant evidence of linkage of antisocial alcoholism to HTR1B G861C ( $p=$ $.04)$ and weak evidence $(p=.06)$ of linkage with a nearby short-tandem repeat marker (D6S284). There 
was also evidence of association, with the 183 Finnish antisocial alcoholics having an 861C allele frequency of 0.32 , compared with 0.23 for the other Finns studied, a significant difference $(p=.005)$. In the Southwestern American Indian tribe, sib pair analysis showed linkage of antisocial alcoholism to both G861C ( $p=.01)$ and to D6S284 $(p=.01)$.

Huang et al. (1999) examined allele frequencies for the G861C polymorphism using genomic DNA isolated from postmortem brain tissue obtained from 64 alcohol-dependent patients, 36 subjects with pathological aggression, and 102 controls. These investigators found no evidence for allelic association to either $A D$ or pathological aggression. Furthermore, binding indices of the 5-HT1B receptor in prefrontal cortex did not differentiate between controls and alcoholics or between controls and subjects with pathological aggression (Huang et al. 1999). However, $B_{\max }$ values for 5-HT1B binding were significantly higher among individuals homozygous for the G861 allele (Huang et al. 1999), which was interpreted to mean that this allele may be in LD with a variant that affects 5-HT1B receptor expression. Mundo et al. (2000) reported linkage disequilibrium of the $861 \mathrm{G}$ allele with obsessive-compulsive disorder.

In light of these findings, we examined LD across three polymorphic systems in the 5-HT1B gene, as well as evidence for allelic association to SD generally and AD specifically, either with or without comorbid ASPD. We hypothesized that a functional effect was more plausible for G-261T than for G861C (because, based on its $5^{\prime}$ location, the former was more likely to have an effect on transcription than the latter), that LD exists between the G-261T and the G861C polymorphisms, and that both would be associated to antisocial SD.

\section{METHODS}

\section{Subjects}

We examined allele frequencies in 370 European Americans (EAs) and 123 African Americans (AAs). Of this number, 278 EAs and 69 AAs met lifetime DSM-III-R criteria (American Psychiatric Association 1987) for alcohol, cocaine, or opioid dependence or a combination of these disorders. Diagnoses were made using the Structured Clinical Interview for DSM-III-R (SCID; Spitzer et al. 1992), the computerized Diagnostic Interview Schedule for DSM-III-R (C-DIS-R; Blouin et al. 1988), or a checklist comprised of DSM-III-R symptoms. A subsample of 90 patients $(25.9 \%$; 68 EA and 22 AA) comprised the antisocial SD group; these individuals met either full criteria for ASPD (40 EA and 16 AA) or adult criteria only (i.e., no childhood conduct disorder; $28 \mathrm{EA}$ and $6 \mathrm{AA})$. Among the SD patients, a total of 278 (80.1\%; 243 EAs and 35 AAs) met lifetime criteria for
AD. There were 59 EAs and 11 AAs in the antisocial AD group. The majority of control subjects $(104$, or $69.8 \%)$ were screened using either the SCID, the C-DIS-R, or the Schedule for Affective Disorders and Schizophrenia (Spitzer and Endicott 1975) to exclude alcohol or drug dependence; the remaining 45 controls (30.2\%) were screened using an unstructured interview.

Subjects were recruited at the Alcohol Research Center of the University of Connecticut Health Center and the VA Connecticut Healthcare System, West Haven Campus. All subjects gave written informed consent before participating in the study, which was approved by the Institutional Review Board at each of the participating institutions.

\section{Genotyping}

G861C. Genotyping for G861C was accomplished according to the PCR-RFLP method of Lappalainen et al. (1998), but with very slight modifications in the primer sequences (the $5^{\prime}$ primer was extended by one base; resulting sequence: $5^{\prime}$ - gaa aca gac gcc caa cag gac c - $3^{\prime}$; and the $3^{\prime}$ primer was extended by two bases; resulting sequence: $5^{\prime}$ - cca gaa acc gcg aaa gaa gat tc $-3^{\prime}$ ) (the variant site is detected by HincII, which digests the " $\mathrm{C}$ " allele; there is also a constant HincII digestion site in the PCR product).

G-261T. Genotyping for the G-261T system was done using the PCR-RFLP method of Nöthen et al. (1994), which uses a modified reverse primer that introduces an artificial restriction site (the variant site is detected by BsmA1, which digests the " $\mathrm{T}$ " allele).

C129T. Genotyping for the C129T system was done using primers SNP3artU2 ( $5^{\prime}$-ca agg act aca ttt acc agg acG c - $3^{\prime}$ ) and SNP3D2 (5' - ggt gcg gta cac tgt ggc a - $\left.3^{\prime}\right)$, which yield a 127-bp PCR product. The primers were designed with reference to the Whitehead SNP database (Cargill et al. 1999) and to Entrez sequence accession M75128 (Demchyshyn et al. 1992). An artificial site is introduced via the forward primer (uppercase " $G$ ") (the variant site is detected by BsaHI, which digests the "C" allele).

\section{Statistical Analysis}

Initially, deviation from the genotype counts predicted by Hardy-Weinberg equilibrium expectations was tested using an exact test, as described by Weir (1996) and implemented in software written by Lewis and Zaykin (2001; Genetic Data Analysis (GDA), version 1.0 (d16c)).

Allele frequencies were compared separately by population group. Chi-square analysis was used to compare allele frequencies for three diagnostic groups: control subjects, subjects with a lifetime SD diagnosis (alcohol and/or drug dependence) but no antisocial diagnosis, and subjects with both SD (alcohol and/or drug 
dependence) and antisocial diagnoses. A comparable analysis was then conducted in which the only SD diagnosis examined was AD (either with or without an antisocial diagnosis). Given the comparatively small number of subjects with both SD and an antisocial diagnosis, overlapping analyses served to maximize the likelihood of finding differences by diagnostic group, should such differences exist. Because the C129T system is in nearcomplete linkage disequilibrium with the G861C system, and because a basis for comparison exists in the literature for the G861C system, of those two polymorphic systems, statistical comparisons are reported only for the G861C system to avoid redundancy.

Haplotype analysis was performed using version 5.0 of the 3LOCUS program (Long et al. 1995), which computes estimated haplotype frequencies using an expectation maximization (EM) algorithm, as well as pairwise disequilibria. Values of $\mathrm{D}^{\prime}$, a standardized measure of LD (Lewontin 1988), were also computed. LD was further evaluated using an exact test implemented with GDA version 1.0 (d16c) software; probability levels as computed by GDA are estimates of significance based on a shuffling test (Lewis and Zaykin 2000, 2001). Both haplotype frequencies and LD were examined separately by diagnosis and population group.

\section{RESULTS}

There was no deviation from HW expectations at any of the loci for any of the diagnostic groups in either of the populations. Frequencies for HTR1B alleles by population and diagnosis are shown in Table 1. Among both EAs and AAs, there was no evidence of allelic association with either $\mathrm{SD}$ or $\mathrm{AD}$, with or without a comorbid antisocial diagnosis.

Among EAs, all comparisons between controls and diagnostic groups for the two polymorphic systems were non-significant. For the G861C polymorphism: SD subjects without an antisocial diagnosis, $\chi^{2}(1)=1.04, p=$ .31; $\mathrm{SD}$ subjects with an antisocial diagnosis, $\chi^{2}(1)=$ $0.72, p=.40$; AD subjects without an antisocial diagnosis, $\chi^{2}(1)=1.17, p=.28$; AD subjects with an antisocial diagnosis, $\chi^{2}(1)=0.72, p=.40$. For the G-261T polymorphism: SD subjects without an antisocial diagnosis, $\chi^{2}(1)=0.56, p=.45 ;$ SD subjects with an antisocial diagnosis, $\chi^{2}(1)=0.63, p=.43$; AD subjects without an antisocial diagnosis, $\chi^{2}(1)=0.69, p=.40 ; \mathrm{AD}$ subjects with an antisocial diagnosis, $\chi^{2}(1)=0.35, p=.55$.

Similarly, among AAs, all comparisons by phenotype for the two polymorphic systems were non-significant. For the G861C polymorphism: SD subjects without an antisocial diagnosis, $\chi^{2}(1)=0.41, p=.52$; SD subjects with an antisocial diagnosis, $\chi^{2}(1)=0.64, p=$ .42; AD subjects without an antisocial diagnosis, $\chi^{2}(1)=$ $0.97, p=.33$; AD subjects with an antisocial diagnosis, $\chi^{2}(1)=0.08, p=.78$. For the G-261T polymorphism: SD subjects without an antisocial diagnosis, $\chi^{2}(1)=1.10, p=$ .30; SD subjects with an antisocial diagnosis, $\chi^{2}(1)=$ $0.72, p=.40$; $\mathrm{AD}$ subjects without an antisocial diagnosis, $\chi^{2}(1)=1.27, p=.26$; AD subjects with an antisocial diagnosis, $\chi^{2}(1)=0.10, p=.75$.

Haplotype frequencies are shown in Table 2. In both populations, irrespective of diagnosis and consistent with the report of Huang et al. (1999), there was almost complete LD between the G861C and the C129T systems $(p<.0001)$. Among EAs, both in control and substance-dependent subjects, there was also strong evidence of LD between the G-261T system and the other two polymorphic systems $(p<.001)$ (see Table 3 ).

\section{DISCUSSION}

The findings reported provide evidence for near-complete LD between two presumably nonfunctional HTR1B polymorphisms (G861C and C129T) in both EA and AA samples, consistent with the report of Huang et al. (1999) and irrespective of diagnosis. There was also strong evidence in EAs for LD between each of these polymorphic systems and the G-261T polymorphism in the $5^{\prime}$ flanking region of HTR1B. In AAs, there was weak evidence for LD between G-261T and the C129T system, but only in substance-dependent subjects. As indicated by the magnitude of the $\mathrm{D}^{\prime}$, this is due only in part to the smaller sample sizes in this population. Evidence of LD between G861C and G-261T is of interest in view of the possibility that G-261T, given its location, could affect the transcriptional activity of HTR1B. Such a finding would help to explain the allelic association of G861C with antisocial alcoholism reported by Lappalainen et al. (1998) and the greater 5-HT1B receptor density among individuals homozygous for the G861 allele reported by Huang et al. (1999). However, our data did not provide evidence for association of this polymorphism to SD or AD, with or without a comorbid antisocial diagnosis. The lack of association is consistent with the findings of Huang et al. (1999), who found no association of G861C alleles to either pathological aggression or AD.

In both populations studied, the three most common haplotypes (-261G/129C/861G (GCG), -261T/129T/ 861C (TTC), and $-261 \mathrm{~T} / 129 \mathrm{C} / 861 \mathrm{G}$ (TCG)) account for $>96 \%$ of the observations. Consistent with this haplotype distribution, in both populations the $861 \mathrm{C}$ allele is seen exclusively, or nearly exclusively, on haplotypes with the $-261 \mathrm{~T}$ allele, whereas the $861 \mathrm{G}$ chromosomes are divided by G-261T genotype. While for each individual polymorphic system, the major allele is similar between AAs and EAs, for haplotypes, TCG is most common in AAs, and GCG is most common in EAs (close to $50 \%$ in each case). Thus, especially where the 
Table 1. HTR1B Allele Frequencies (Number of Alleles) in Patients with Substance Dependence or Alcohol Dependence [Without or With a Comorbid Antisocial Personality Disorder (ASPD) Diagnosis], by Population Group

\begin{tabular}{|c|c|c|c|c|c|}
\hline Alleles by Population & Controls & $\begin{array}{c}\text { Substance } \\
\text { Dependence } \\
\text { without ASPD }\end{array}$ & $\begin{array}{c}\text { Antisocial } \\
\text { Substance } \\
\text { Dependence }\end{array}$ & $\begin{array}{c}\text { Alcohol } \\
\text { Dependence } \\
\text { without ASPD }\end{array}$ & $\begin{array}{c}\text { Antisocial } \\
\text { Alcohol } \\
\text { Dependence }\end{array}$ \\
\hline European-Americans: & $(2 \mathrm{~N}=184)$ & $(2 \mathrm{~N}=420)$ & $(2 \mathrm{~N}=136)$ & $(2 \mathrm{~N}=368)$ & $(2 \mathrm{~N}=118)$ \\
\hline $861 G$ & $.81(136)$ & $.77(305)$ & $.76(96)$ & $.76(267)$ & $.76(82)$ \\
\hline $861 C$ & $.19(32)$ & $.23(93)$ & $.24(30)$ & $.24(83)$ & $.24(26)$ \\
\hline $129 \mathrm{C}$ & $.83(115)$ & $.76(277)$ & $.77(95)$ & $.75(241)$ & $.76(82)$ \\
\hline $129 \mathrm{~T}$ & $.17(23)$ & $.24(87)$ & $.23(29)$ & $.25(81)$ & $.24(26)$ \\
\hline$-261 \mathrm{~T}$ & $.47(70)$ & $.51(176)$ & $.53(63)$ & $.52(158)$ & $.52(54)$ \\
\hline$-261 G$ & $.53(78)$ & $.49(166)$ & $.47(57)$ & $.48(146)$ & $.48(50)$ \\
\hline African-Americans: & $(2 \mathrm{~N}=108)$ & $(2 \mathrm{~N}=94)$ & $(2 \mathrm{~N}=44)$ & $(2 \mathrm{~N}=48)$ & $(2 \mathrm{~N}=22)$ \\
\hline $861 G$ & $.75(72)$ & $.80(72)$ & $.67(28)$ & $.84(37)$ & $.75(15)$ \\
\hline $861 C$ & $.25(24)$ & $.20(18)$ & $.33(14)$ & $.16(7)$ & $.25(5)$ \\
\hline $129 \mathrm{C}$ & $.78(62)$ & $.82(69)$ & $.67(28)$ & $.85(39)$ & $.75(15)$ \\
\hline $129 \mathrm{~T}$ & $.22(18)$ & $.18(15)$ & $.33(14)$ & $.15(7)$ & $.25(5)$ \\
\hline$-261 \mathrm{~T}$ & $.79(74)$ & $.71(58)$ & $.70(31)$ & $.68(30)$ & $.73(16)$ \\
\hline$-261 G$ & $.21(20)$ & $.29(24)$ & $.30(13)$ & $.32(14)$ & $.17(6)$ \\
\hline
\end{tabular}

Comparisons among European Americans: Controls vs. Substance-Dependent Patients and vs. Alcohol-Dependent Patients, with or without comorbid ASPD yielded a range of $\chi 2$ values $=0.35-1.05, \mathrm{df}=1, p>.10$.

Comparisons among African Americans: Controls vs. Substance-Dependent Patients and vs. Alcohol-Dependent Patients, with or without comorbid ASPD yielded a range of $\chi 2$ values $=0.08-1.27, \mathrm{df}=1, p>.10$.

allele of interest for genetic association was 861G (as for possible linkage disequilibrium with obsessive-compulsive disorder, reported by Mundo et al. (2000)), genotyping the G-261T system as well is likely to provide additional information. Although these data do not bear on the question of whether either the G861C system or the G-261T system is functional, if the latter is functional and the former is not, the strong LD seen between the systems could provide an explanation for observed positive association findings. The LD data show that genotyping the T129C system is much less likely to provide additional useful information.

Differences in the definition of the phenotypes in the populations examined both in the present report and in the study by Huang et al. (1999) may have contributed to the failure to replicate the findings of Lappalainen et al. (1998). Huang et al. (1999) did not study subjects with comorbid $\mathrm{AD}$ and pathological aggression. In the present study, antisocial SD was defined by the presence of SD and a comorbid antisocial diagnosis. Lappa- lainen et al. (1998) studied only antisocial alcoholism, which was determined by the concurrent presence of $\mathrm{AD}$ and either ASPD or intermittent explosive disorder. It is possible that the association reported by Lappalainen et al. (1998) was limited to alcohol-dependent patients with particularly high levels of impulsivity (i.e., those with intermittent explosive disorder). The inclusion in the present study of antisocial individuals based on the presence of either full diagnostic criteria (i.e., including childhood conduct disorder) or adult antisocial features contributes to diagnostic heterogeneity both in present study and in relation to the studies of Lappalainen et al. (1998) and Huang et al. (1999). The studies also differed with respect to the process and source of subject recruitment and the populations studied. In the present study, EA and AA subjects were recruited primarily from a substance abuse treatment setting. In contrast, Lappalainen et al. (1998) recruited subjects from criminal/forensic settings in Finland and from a Native American (Amerindian) community. It is plausi-

Table 2. Estimated Haplotype Frequencies

\begin{tabular}{|c|c|c|c|c|}
\hline \multirow[b]{2}{*}{ Haplotype (short name) } & \multicolumn{2}{|c|}{ African American } & \multicolumn{2}{|c|}{ European American } \\
\hline & $\begin{array}{l}\text { Control } \\
(2 \mathrm{~N}=72)\end{array}$ & $\begin{array}{l}\text { Substance Dependent } \\
\qquad(2 \mathrm{~N}=114)\end{array}$ & $\begin{array}{l}\text { Control } \\
(2 \mathrm{~N}=120)\end{array}$ & $\begin{array}{l}\text { Substance Dependent } \\
(2 \mathrm{~N}=422)\end{array}$ \\
\hline$-261 \mathrm{~T} / 129 \mathrm{C} / 861 \mathrm{C}(\mathrm{TCC})$ & 0.014 & 0 & 0 & 0.007 \\
\hline$-261 G / 129 C / 861 G(G C G)$ & 0.236 & 0.236 & 0.525 & 0.467 \\
\hline$-261 \mathrm{~T} / 129 \mathrm{~T} / 861 \mathrm{G}(\mathrm{TTG})$ & 0.014 & 0 & 0 & 0.007 \\
\hline$-261 \mathrm{~T} / 129 \mathrm{~T} / 861 \mathrm{C}(\mathrm{TTC})$ & 0.236 & 0.219 & 0.167 & 0.222 \\
\hline$-261 \mathrm{~T} / 129 \mathrm{C} / 861 \mathrm{G}$ (TCG) & 0.500 & 0.518 & 0.308 & 0.287 \\
\hline$-261 G / 129 \mathrm{~T} / 861 \mathrm{C}(\mathrm{GTC})$ & 0 & 0.027 & 0 & 0.010 \\
\hline
\end{tabular}


Table 3. Pairwise Linkage Disequilibrium (D) and Standardized Linkage Disequilibrium (D') Values and Probabilities for the Three Polymorphic Systems

\begin{tabular}{|c|c|c|c|c|c|c|c|c|c|c|c|c|}
\hline \multirow{3}{*}{ Polymorphic Systems } & \multicolumn{6}{|c|}{ African American } & \multicolumn{6}{|c|}{ European American } \\
\hline & \multicolumn{3}{|c|}{$\begin{array}{c}\text { Control } \\
(2 \mathrm{~N}=108)\end{array}$} & \multicolumn{3}{|c|}{$\begin{array}{l}\text { Substance Dependent } \\
\qquad(2 \mathrm{~N}=138)\end{array}$} & \multicolumn{3}{|c|}{$\begin{array}{c}\text { Control } \\
(2 \mathrm{~N}=184) \\
\end{array}$} & \multicolumn{3}{|c|}{$\begin{array}{l}\text { Substance Dependent } \\
\qquad(2 \mathrm{~N}=566)\end{array}$} \\
\hline & $\mathrm{D}$ & $\mathrm{D}^{\prime}$ & $\mathrm{P}$ & $\mathrm{D}$ & $\mathrm{D}^{\prime}$ & $\mathrm{P}$ & $\mathrm{D}$ & $\mathrm{D}^{\prime}$ & $\mathrm{P}$ & $\mathrm{D}$ & $\mathrm{D}^{\prime}$ & $\mathrm{P}$ \\
\hline$-261 \mathrm{~T} / 129 \mathrm{~T}$ & 0.056 & 1.000 & .404 & 0.038 & 0.585 & .132 & 0.088 & 1.000 & .0005 & 0.104 & 0.914 & $<.0001$ \\
\hline$-261 \mathrm{~T} / 861 \mathrm{C}$ & 0.056 & 1.000 & .165 & 0.038 & 0.585 & .402 & 0.088 & 1.000 & .0004 & 0.104 & 0.914 & $<.0001$ \\
\hline $129 \mathrm{~T} / 861 \mathrm{C}$ & 0.173 & 0.961 & $<.0001$ & 0.185 & 1.000 & $<.0001$ & 0.139 & 1.000 & $<.0001$ & 0.175 & 0.961 & $<.0001$ \\
\hline
\end{tabular}

ble that a physiologically meaningful association is confined to certain populations, or is detectable through linkage disequilibrium with G861C only in certain populations (the Finns and Southwestern American Indians are both special populations, from a genetic perspective). The present results showing differences in haplotype frequency between AA and EA populations, and specifically, different allocation of promoter system alleles with G861C alleles by populations, is consistent with this possibility.

It is also possible that we failed to detect an association due to statistical power limitations imposed by the sample size. The effect size (w) for in the study by Lappalainen et al. (1998) was 0.08 (which is in the small range of effect sizes) for the comparison of controls with antisocial alcoholics. Based on this estimate, and $\alpha=.05$, among EAs the comparison of controls with antisocial substance-dependent subjects in the current study provided power of $30 \%$ to detect such an effect. However, the effect size for the comparison of non-antisocial alcoholics with antisocial alcoholics in the study by Lappalainen et al. was 0.11. Based on this effect size, the sample in the present study yielded power $=0.74$ (with $\alpha=$ .05) for the comparison within the sample of EAs with substance dependence (i.e., those with or without an antisocial diagnosis). Although we did not compare these groups statistically in the present study, Table 1 shows an identical allele frequency for the two substance-dependent groups. This suggests that the failure to replicate the findings of Lappalainen et al. (1998) is not due to inadequate statistical power. We conducted multiple statistical comparisons in order to maximize the likelihood of replicating results reported by Lappalainen et al. (1998). The potential problem with such an approach is that it increases the Type 1 error rate. However, since we found no significant association, this concern does not appear to be relevant in the present context.

Because of its important theoretical and clinical implications, further examination of the relationship of HTR1B alleles with antisocial alcohol and/or drug dependence in larger samples is warranted. Given the potential for population stratification to produce a spurious association, it would be important for subsequent studies to examine evidence of such an effect (Pritchard and Rosenberg 1999) and, when identified, to control for it (Pritchard et al. 2000). Alternatively, a familybased approach, such as the haplotype relative risk method (Falk and Rubinstein 1987) or transmission disequilibrium test (Spielman et al. 1993) might be used. In addition, refinement of the diagnosis of antisocial SD (e.g., based on electrophysiologic or neuroendocrine markers of alcohol dependence or impulsivity) may provide a better phenotype for examination of the association to alleles of HTR1B.

\section{ACKNOWLEDGMENTS}

J. Lappalainen, M.D., Ph.D., made helpful comments on the manuscript. A. Lacobelle, R. Capper, P. Fall, C. Petrus, K. Bonvicini, and K. Beazoglou provided excellent technical assistance. This work was supported by funds from the U.S. Department of Veterans Affairs (the VA Medical Research Program and the VA Connecticut-Massachusetts Mental Illness Research, Education and Clinical Center (MIRECC)), NIMH grant K02-MH01387, NIAAA grants R01-AA11330, K02-AA00239, and P50-AA03510, and NCRR grant M01-RR06192 (University of Connecticut General Clinical Research Center).

\section{REFERENCES}

Adham N, Romanienko P, Hartig P, Weinshank RL, Branchek $\mathrm{T}$ (1992): The rat 5-hydroxytryptamine-1B receptor is the species homologue of the human 5-hydroxytryptamine1D beta receptor. Mol Pharmacol 41:1-7

American Psychiatric Association (1987): Diagnostic and Statistical Manual of Mental Disorders, Third Edition, revised. Washington DC, American Psychiatric Press

Babor TF, Hofmann M, DelBoca FK, Hesselbrock V, Meyer RE, Dolinsky ZS, Rounsaville B (1992): Types of alcoholics, I. Evidence for an empirically derived typology based on indicators of vulnerability and severity. Arch Gen Psychiatry 49:599-608

Ball SA, Carroll KM, Babor TF, Rounsaville BJ (1995): Subtypes of cocaine abusers: support for a type A-type B distinction. J Consult Clin Psychol 63:115-124 
Ball SA, Kranzler HR, Tennen H, Poling JC, Rounsaville BJ (1998): Personality disorder and dimension differences between type A and type B substance abusers. J Pers Dis $12: 1-12$

Blouin AG, Perez EL, Blouin JH (1988): Computerized administration of the diagnostic interview schedule. Psychiatr Res 23:335-344

Bohman M, Cloninger R, Sigvardsson S, von Knorring AL (1987): The genetics of alcoholisms and related disorders. J Psychiatric Res 21:447-52

Brodie MS, Bunney EB (1996): Serotonin potentiates dopamine inhibition of ventral tegmental area neurons in vitro. J Neurophysiol 76:2077-2082

Cadoret RJ, Troughton E, O'Gorman TW, Heywood E (1986): An adoption study of genetic and environmental factors in drug abuse. Arch Gen Psychiatry 43:1131-1136

Cadoret RJ, Yates WR, Troughton E, Woodworth G, Stewart MA (1995): Adoption study demonstrating two genetic pathways to drug abuse. Arch Gen Psychiatry 52:42-52

Cargill M, Altshuler D, Ireland J, Sklar P, Ardlie K, Patil N, Lane CR, Lim EP, Kalyanaraman N, Nemesh J, Ziaugra L, Friedland L, Rolfe A, Warrington J, Lipshutz R, Daley GQ, Lander ES (1999): Characterization of single-nucleotide polymorphisms in coding regions of human genes. Nat Genet 22:231-238

Cleare AJ, Bond AJ (1995): The effect of tryptophan depletion and enhancement on subjective and behavioral aggression in normal male subjects. Psychopharmacol 118:72-81

Crabbe JC, Belknap JK, Buck KJ (1994): Genetic animal models of alcohol and drug abuse. Science 264:1715-1723

Crabbe JC, Phillips TJ, Feller DJ, Hen R, Wenger CD, Lessov CN, Schafer GL (1996): Elevated alcohol consumption in null mutant mice lacking 5-HT1B serotonin receptors. Nat Genet 14:98-101

Demchyshyn L, Sunahara RK, Miller K, Teitler M, Hoffman BJ, Kennedy JL, Seeman P, Van Tol HH, Niznik HB (1992): A human serotonin 1D receptor variant (5HT1D beta) encoded by an intronless gene on chromosome 6 . Proc Natl Acad Sci USA 89:5522-5526

Di Chiara G, Imperato A (1988): Drugs abused by humans preferentially increase synaptic dopamine concentrations in the mesolimbic system of freely moving rats. Proc Natl Acad Sci 85:5274-5278

Falk CT, Rubinstein P (1987): Haplotype relative risks: An easy reliable way to construct a proper control sample for risk calculations. Ann Hum Genet 51:227-233

Feingold A, Ball SA, Kranzler HR, Rounsaville BJ (1996): Generalizability of the type A/type B Distinction across different psychoactive substances. Am J Drug Alcohol Abuse 22:449-462

Higley JD, Mehlman PT, Taub DM, Higley SB, Suomi SJ, Linnoila M, Vickers JH (1992): Cerebrospinal fluid monoamine and adrenal correlates of aggression in free-ranging rhesus monkeys. Arch Gen Psychiatry 49:436-441

Higley JD, Suomi SJ, Linnoila M (1996): A nonhuman primate model of type II excessive alcohol consumption? Part 2. Diminished social competence and excessive aggression correlates with low cerebrospinal fluid 5-hydroxyindolacetic acid concentrations. Alcohol Clin Exp Res 20:643-650

Huang Y, Grailhe R, Arango V, Hen R, Mann J (1999): Rela- tionship of psychopathology to the human serotonin 1B genotype and receptor binding kinetics in postmortem brain tissue. Neuropsychopharmacol 21:238-246

Julius D (1991): Molecular biology of serotonin receptors. Annual Review of Neuroscience 14:335-360

Kessler RC, McGonagle KA, Zhao S, Nelson CB, Hughes M, Eshleman S, Wittchen H-U, Kendler KS (1994): Lifetime and 12-month prevalence of DSM-III-R psychiatric disorders in the United States: Results from the National Comorbidity Survey. Arch Gen Psychiatry 51:8-19

Kessler RC, Nelson CB, McGonagle KA, Edlund MJ, Frank RG, Leaf PJ (1996): The epidemiology of co-occurring addictive and mental disorders: implications for prevention and service utilization. Am J Orthopsychiatry 66:17-31

Kriem B, Abraini JH, Rostain JC (1996): Role of 5-HT1b receptor in the pressure-induced behavioral and neurochemical disorders in rats. Pharmacol Biochem Behav 53:257-264

Lappalainen J, Dean M, Charbonneau L, Virkkunen M, Linnoila M, Goldman D (1995): Mapping of the serotonin 5-HT1D beta autoreceptor gene on chromosome 6 and direct analysis for sequence variants. Am J Med Genet 60:157-161

Lappalainen J, Long JC, Eggert M, Ozaki N, Robin RW, Brown GL, Naukkarinen H, Virkkunen M, Linnoila M, Goldman D (1998): Linkage of antisocial alcoholism to the serotonin 5-HT1B receptor gene in two populations. Arch Gen Psychiatry 55:989-994

Lewis PO, Zaykin D (2000): Genetic Data Analysis: Computer program for the analysis of allelic data. Version 1.0 (d15). Free program distributed by the authors over the internet from the GDA Home Page at http:// alleyn.eeb.uconn.edu/gda/

Lewis PO, Zaykin D (2001): Genetic data analysis. Computer program for the analysis of allelic data. Version 1.0 (d16c). Free program distributed by the authors over the internet from http://lewis.eeb.uconn.edu/lewishome/software.html

Lewontin R (1988): On measures of gametic disequilibrium. Genetics 120:849-852

Limson R, Goldman D, Roy A, Lamparski D, Ravitz B, Adinoff B, Linnoila M (1991): Personality and cerebrospinal fluid monoamine metabolites in alcoholics and controls. Arch Gen Psychiatry 48:437-441

Long JC, Williams RC, Urbanek M (1995): An E-M algorithm and testing strategy for multiple-locus haplotypes. Am J Hum Genet 56:799-810

Maroteaux L, Saudou F, Amlaiky N, Boschert U, Plassat JL, Hen R (1992): Mouse $5 \mathrm{HT}_{1 \mathrm{~B}}$ Serotonin receptor: cloning, functional expression, and localization in motor control centers. Proc Natl Acad Sci 89:3020-3024

Moss HB, Yao JK, Panzak GL (1990): Serotoninergic responsivity and behavioral dimensions in antisocial personality disorder with substance abuse. Biol Psychiatry 28:325-338

Mundo E, Richter MA, Sam F, Macciardi F, Kennedy JL (2000): Is the 5-HT(1Dbeta) receptor gene implicated in the pathogenesis of obsessive-compulsive disorder? Am J Psychiatry 157:1160-1161

Nöthen MM, Erdmann J, Shimron-Abarbanell D, Propping P 
(1994): Identification of genetic variation in the human serotonin 1D beta receptor gene. Biochem Biophys Res Commun 205:1194-1200

O'Keane V, Moloney E, O'Neill H, O’Vonner A, Smith C, Dinan TG (1992): Blunted prolactin responses to D-fenfluramine in sociopathy: Evidence for subsensitivity of central serotoninergic function. Br J Psychiatry 160:643-646

Parsons LH, Weiss F, Koob GF (1998): Serotonin 1B receptor stimulation enhances cocaine reinforcement. J Neurosci 18:10078-10089

Pihl RO, Young SN, Harden P, Plotnick S, Chamberlain B, Ervin FR (1995): Acute effect of altered tryptophan levels and alcohol on aggression in normal human males. Psychopharmacol 119: 353-360

Pritchard JK, Rosenberg NA (1999): Use of unlinked genetic markers to detect population stratification in association studies. Am J Hum Genet 65:220-228

Pritchard JK, Stephens M, Rosenberg NA, Donnelly P (2000): Association mapping in structured populations. Am J Hum Genet 67:170-181

Regier DA, Farmer ME, Rae DS, Locke BZ, Keith SJ, Judd LL, Goodwin FK (1990): Comorbidity of mental disorders with alcohol and other drug abuse. Results from the Epidemiologic Catchment Area (ECA) Study. JAMA 264:2511-2518

Rocha BA, Scearce-Levie K, Lucas JJ, Hiroi N, Castanon N, Crabbe JC, Nestler EJ, Hen R (1998a): Increased vulnerability to cocaine in mice lacking the serotonin-1B receptor. Nature 393:175-178

Rocha BA, Fumagalli F, Gainetdinov RR, Jones SR, Ator R, Giros B, Miller GW, Caron MG (1998b): Cocaine selfadministration in dopamine-transporter knockout mice. Nature Neurosci 1:132-137

Saudou F, Amara DA, Dierich A, LeMeur M, Ramboz S, Segu L, Buhot MC, Hen R (1994): Enhanced aggressive behavior in mice lacking 5-HT1B receptor. Science 265:1875-1878

Sidenberg DG, Bassett AS, Demchyshyn L, Niznik HB, Mac- ciardi F, Kamble AB, Honer WG, Kennedy JL (1993): New polymorphism for the human serotonin 1D receptor variant (5-HT1D beta) not linked to schizophrenia in five Canadian pedigrees. Hum Hered 43:315-318

Soubrie P (1986): Reconciling the role of central serotonin neurons in human and animal behavior. Behav Brain Sci 9:319-364

Spielman RS, McGinnis RE, Ewens WJ (1993): Transmission test for linkage disequilibrium: the insulin gene region and insulin-dependent diabetes mellitus (IDDM). Am J Hum Genet 52:506-516

Spitzer RL, Endicott J (1975): Schedule for Affective Disorders and Schizophrenia: Lifetime version. New York Biometrics Research Division, New York State Psychiatric Institute

Spitzer RL, Williams JBW, Gibbon M, First MB (1992): The Structured Clinical Interview for DSM-III-R (SCID), I: History, rationale and description. Arch Gen Psychiatry 49:624-629

Verheul R, Ball SA, van den Brink W (1998): Substance abuse and personality disorders. In Kranzler HR, Rounsaville BJ (eds), Dual Diagnosis and Treatment: Substance Abuse and Comorbid Medical and Psychiatric Disorders. New York, Marcel Dekker, pp 317-363

Virkkunen M, Rawlings R, Tokola R, Poland RE, Guidotti A, Nemeroff C, Bissette G, Kalogeras K, Karonen S-L, Linnoila M (1994): CSF biochemistries, glucose metabolism, and diurnal activity rhythms in alcoholic violent offenders, fire setters, and healthy volunteers. Arch Gen Psychiatry 51:20-27

Voigt MM, Laurie DJ, Seeburg PH, Bach A (1991): Molecular cloning and characterization of a rat brain cDNA encoding a 5-hydroxytryptamine1B receptor. EMBO J 10:4017-4023

Weir BS (1996): Genetic Data Analysis II. Methods for Discrete Population Genetic Data. Sunderland, MA, Sinauer Associates

Zifa E, Fillion G (1992): 5-Hydroxytryptamine receptors. Pharmacological Reviews 44: 401-458 